\title{
Turist Rehberleri Açısından İş Doyumunun Önemi
}

\section{The Importance of Job Satisfaction in Terms of Tourist Guides}

\author{
Arş.Gör. Ali KABAKULAK \\ Afyon Kocatepe Üniversitesi, Turizm Fakültesi, Türkiye \\ Afyon Kocatepe University, Faculty of Tourism, Turkey \\ Orcid Id: https://orcid.org/0000-0001-9256-8557 - alikabakulak@aku.edu.tr
}

\begin{abstract}
Özet
Amaç ve Önem: Bu çalışmanın amacı, turist rehberleri açısından iş doyumunun öneminin ortaya konularak ilgililere öneriler getirmektir. Turist rehberlerinin elde edeceği iş doyumu hem kendileri hem de işveren konumundaki acenteler için hem de hizmet verecekleri turistler için önemlidir. Bu nedenle turist rehberlerinin işlerinden elde ettikleri doyumların araştırılması önemli bir konu olarak değerlendirilmektedir.

Yöntem: Bu çalışmada literatür taraması yöntemi kullanılmış ve konuyla ilgili gerçekleștirilmiş çalışmalardan elde edilen bilgiler derlenerek, ilgili çalışmalarda ortaya çıkan sonuçlar doğrultusunda ilgili taraflara öneriler getirilmiştir.

Bulgular: Yapılan literatür taraması kapsamında turist rehberlerinin iş doyum düzeyleri ortaya konularak turist rehberleri açısından iş doyumunun önemi vurgulanmıştır. Söz konusu literatür taramasında incelenen çalışmalarda direkt olarak turist rehberlerinin iş doyumunu ortaya koyacak çalışmaların oldukça sınırlı olduğu gözlenmiş, incelenen çalışmalarda da turist rehberlerinin çeşitli sorunlarından dolayı iş doyum düzeylerinin pek de istedikleri seviyede olmadığı saptanmıştır. Bu sonuçlar doğrultusunda, işveren konumundaki acentelere ve Turist Rehberleri Birliği’ne (TUREB) bu kapsamda öneriler getirilmeye çalışılmıştır.
\end{abstract}

Sınırlııklar: Bu çalışma ağırlıklı olarak turizm ve özellikle turist rehberleri üzerine konuyla ilgili gerçekleştirilmiş çalışma sonuçları ve bunların değerlendirilmesi ile sınırlıdır.

Anahtar Kelimeler: Turist, turist rehberi, iş doyumu

Makale Türü: Literatür taraması

\begin{abstract}
Purpose and Importance: The aim of this study is to make recommendations about the subject of job satisfaction in terms of tourist guides. The job satisfaction of tourist guides is important for both themselves and for the employers' agents as well as for the tourists they serve. For this reason, the search for the satisfaction that the tourist guides get from their work is considered as an important issue.
\end{abstract}

Methodology: In this study, the literature search method was used and the information obtained from the studies carried out on the topic was compiled and suggestions were made to the related parties according to the results of the related studies

Findings: Within the scope of the literature survey, the level of job satisfaction of tourist guides has been revealed and the importance of job satisfaction has been emphasized in terms of tourist guides. It has been observed that the work to be done by the tourist guides is very limited in the works that are examined in the literature survey and it is found that the tourist guides are not in the level that their job satisfaction level is very desired due to the problems of the tourists. In line with these results, the 
Agency and the Tourist Guides Association (TUREB), which are the employers, have tried to make suggestions within this scope.

Limitations: This study is mainly limited to the results of the studies carried out on tourism and especially on tourist guides and their evaluation

Keywords: Tourist, Tourist Guides, Job Satisfaction.

Paper Type: Literature review

\section{Giriş}

Hangi faaliyet alanında çalışılırsa çalışılsın hedef ve başarı, çalışan memnuniyetine bağlıdır ve organizasyonel başarı ve büyümeye katkıda bulunur, üretkenliği ve işin kalitesini artırır (Latif et al., 2013). Turist rehberi, turizm sektörünün en önemli temsilcilerinden biri olarak tanımlanmaktadır. Turist rehberleri, birçok karmaşık ve farklı rollere sahiptirler (Rabotic, 2010: 3). Turist rehberlerinin temel sorumluluğu, bilgi aktarımı yaparken turistlere bu bilgi aktarımını eğlenceli bir şekilde ve uygun tarzda yapmaktır (Boyle and Arnott, 2004: 75). Turist rehberleri tur süresi boyunca turistlerle sürekli ve maksimum düzeyde iletişim halindedirler ki bu durum turistlerin memnuniyet seviyelerinin yüksek olmasını sağlamada en önemli unsurlardan biridir (Geva and Goldman 1991: 178).

İş hayatı, insan yaşamının önemli yönlerinden birini oluşturmakta ve insanlar yaşamlarının büyük bir bölümünü bir iş yaparak geçirmektedirler. Eğer yapılan iş, bireyin istediği gibi sonuçlandiysa birey motive olmakta ve doyum elde etmekte, sonuç beklenen düzeyde değil ise birey için iş doyumsuzluğu söz konusu olabilmektedir. Ayrıca işgörenin iş doyumunun yüksek olması, performans artışı ve üretkenlik gibi yönleriyle bireyler açısından yararlar sağlarken; verimlilik artışı, düşük düzeyli personel devir hızı, nitelikli işgörenleri işletmeye çekme gibi yönleriyle de işletmelere büyük katkılar sağlamaktadır (Köroğlu, 2012: 275).

İş doyumu, bir alt yaşam alanı olarak, bireylerin yaşam doyumlarını doğrudan etkileyen bir kavramdır. İnsanı geliştirme, doyumlu kılma, zenginleştirme çabası, tarih boyunca öncelikli olarak dikkate alınan bir etkinliktir. Bireyin iş ortamında yetenek, beceri, ilişki gibi özelliklerinin geliştirilmesi; onun yaşamını anlamlı ve değerli bulmasında önemli etkendir (Keser, 2005: 78).

$\mathrm{Bu}$ çalışmada turist rehberlerinin iş doyumları üzerinde durulmuştur. İş doyumunun turist rehberleri açısından ne kadar önemli olduğu ortaya konarak işverenlerin, turist rehberlerinin işlerinden ne kadar doyum ve müşteri memnuniyeti sağladıkları tespit edilerek turist rehberlerinin mesleklerini icra ederken karşılaştıkları zorluklar en düşük seviyeye indirilmelidir. Böylelikle turist rehberlerinin işten ayrılma niyetleri azalır, mesleklerine karşı olumlu tutum geliştirmelerine yardımcı olmaktadır. İş doyumu her sektör çalışanı açısından olduğu gibi emek yoğun sektörün çalışanı olan ve mesai kavramı olmadan çalışan turist rehberleri açısından da önem arz etmektedir. İş doyumu sağlayan turist rehberi ülkenin tanıtımına, acentenin cirolarının artması, iş verimliliği, işe bağlılık, moral ve motivasyon artışı sağlarken aynı zamanda rehberlerin yaşam doyumlarını ve mesleki tutumlarını arttırır; işi bırakma, başka mesleğe yönelme, iş arkadaşlarıyla geçinememe gibi problemlerini de azaltır. 


\section{Turist Rehberliği}

22.06.2012 tarihinde çıkan yasanın 6326'nolu kanununa göre turist rehberi, T.C. vatandaşı, 18 yaşını doldurmuş, üniversitelerin turist rehberliği bölümlerinin önlisans, lisans veya yüksek lisans programlarından mezun olmuş veya üniversitelerin turist rehberliği bölümü dışındaki diğer bölümlerinden en az lisans düzeyinde mezun olan, Bakanlığın belirlediği Anadolu turunu yapmış, en az bir yabancı dil bilen kişi olarak tanımlanmıştır (TUREB, 2018). Başka bir tanıma göre, ziyaretçilere kendi seçtikleri dilde rehberlik eden ve ilgili makam tarafından verilen ve / veya tanınan çalışma kartına sahip olan ve bir yerin kültürel ve doğal mirasını yorumlayan kişi olarak tanımlanmıştır (WTFGA, 2018).

Turist rehberleri bir ülkenin doğal, tarihi ve kültürel zenginliklerinin tanıtımını yapan kişilerdir ve kritik öneme sahiplerdir. Turist rehberliği mesleği eğlenceli ve kolay yapılabilecek bir meslek olarak algılanmakta, ayrıca dışardan bakıldığında sadece gezmek, eğlenmek, yeni insanlarla tanışmak ve yeni yerler görmek gibi birçok firsat sunuyormuş gibi görünse de gerçekte birçok zorluğu ve sorumluluğu olan bir meslektir (İrigüler ve Güler, 2016: 114).

Bunların yanı sıra turist rehberlerinin, sadece coğrafya, tarih, mimari, müzeler, alışveriş noktaları, en iyi restoranlar ve eğlence merkezleriyle ilgili bilgelere değil aynı zamanda yol güzergâhı, hız limitleri, otel lokasyonları, trafiğin yoğun olduğu saatler, zaman yönetimi, turistlerin güvenliği, şoförle uyum, güncel bilgiler, genel kültür, ilk yardım, anlatım ve konuşma yeteneği, yorum ve espri yeteneği, dişadönüklük ve konukseverlik, uygun giyim tarzı ve mesleki etik kurallara da uygun hareket etmesi gerekir. Turistler, sadece turist rehberlerinin yorumlama ve bilgilendirme becerilerine ve grup dinamiklerinin yönetilmesi konusundaki uzmanlıklarına dayanan tam bir tatmin edici hizmetin yanı sıra, yüksek kalitede bir hizmet ile birlikte benzersiz deneyimlere sahip olmayı ve çeşitliliği aramayı beklemektedir. Bu nedenle turist rehberleri yüksek kalitede hizmet verebilmek için çeşitli profesyonel ve kişisel özelliklerini değerlendirmelidir. Sağlam bir eğitim, sürekli hazırlık yapma ve gerçek yaşam deneyimleri etkin bir rehber için çok gerekli unsurlardır. Turist rehberinin deneyimi, yaratıcılığı, alt yapısı ve adanmışlığı birbirinden ayrı olduğundan her tur eşsizdir ve doğal olarak kişiseldir (İrigüler ve Güler, 2016: 114).

Turistlerin, kaldıkları veya ziyaret ettikleri yerler genellikle gözlem yapmak ve bilgi edinmek için yeterince uzun olmadığı için, turistlerin, rehberlerin söyledikleri ve anlattıklarına güvenmeleri normaldir. Bu noktada, turist rehberi, destinasyon ile ziyaretçileri arasında arabulucu rolü üstlenmektedir (Brito, 2012: 270-275).

\section{2. İş Doyumu}

Vroom'a göre (1964) İş doyumu, işgörenlerin iş yerinde üstlendikleri görevlere karş1 duydukları duyguların yönlendirilmesidir. İş doyumu, çalışan motivasyonu ve daha iyi performansa yönelik teşvik için vazgeçilmez bir unsurdur. Birçok insan, yıllardır iş doyumunu tanımlamaya çalışmıştır (Raziq and Maulabakhsh, 2015: 718).

Birçok araştırmacı tarafından iş doyumunun tanımı farklı şekillerde yapılmıştır. Batı dillerinde "yeterli" anlamındaki Latince "satis" sözcügünden gelen doyum ya da tatmin kavramı (Özaydın ve Özdemir, 2014: 253), sözlük anlamı itibariyle Türk Dil Kurumu'nca (TDK, 2018), "istenen bir şeyin gerçekleşmesini sağlama, gönül doygunluğuna erme, doyum" olarak tanımlanmıştır. İş tatmini denince, işten elde edilen maddi çıkarlar, çalışanın beraberce çalışmaktan zevk aldığı iş arkadaşları ve eser meydana getirmenin sağladığı mutluluk akla gelmektedir (Eren, 2004: 202). İş doyumu, bireyin işini ve işin şartlarını 
değerlendirmesidir (Sinha ve Shukla, 2013: 33). Locke, iş doyumuyla ilgili en kapsamlı tanımı yapmıştır ve iş doyumunu, kişinin işinden ya da işinden edindiği deneyimlerden duyduğu haz, işine karşı olumlu duygular göstermesi olarak tanımlamıştır (Luthans, 2010: 142).

İş doyumu, basit bir ifadeyle bir işgörenin işi ile ne kadar mutlu olduğunun göstergesidir (Vieira, 2005: 39). İş doyumu, işgörenlerin işlerinden duydukları hoşnutluk ya da hoşnutsuzluktur. İşe karşı duyulan hoşnutluk iş doyumunu, işe karşı duyulan hoşnutsuzluk ise iş doyumsuzluğunu göstermektedir (Özdemir, 2006: 70). İş doyumu işin özellikleriyle (özerklik, iş çeşitliliği, iş tanımı, geri bildirim, arkadaşlık ilişkileri) işgörenlerin istekleri birbirine uyduğu zaman gerçekleşmektedir (Ghiselli vd. 2001: 29).

İş doyumu ayrıca örgütlerin etkinliğinin artmasındaki en önemli faktörlerden biri olarak görülebilir. Ortaya atılan yeni yönetim paradigmalarında insana insan gibi muamele edilmesi gerektiği ve işgörenlerin istek, arzu ve ihtiyaçlarının göz önünde bulundurulmasının iş doyumunun önemi açısından en iyi göstergelerden biri olduğu ifade edilebilir. İş doyumu kavramı analiz edildiğinde memnun işgörenin mutlu bir çalışan olduğu ve mutlu bir çalışanın başarılı bir çalışan olduğu mantığı ortaya çıkmaktadır (Aziri, 2011: 77-78).

İş doyumu kavramının önemi, iş doyumsuzluğuna neden olan çalışılan örgüte sadakatsizlik, işten ayrılma ve aksiliklerin artması gibi olumsuzluklar ortaya çıktığında anlaş11ır. Spector (1997) iş doyumunun üç önemli özelliği olduğunu ifade etmiştir. Birincisi, işverenler, işgörenlere adaletli ve saygılı davranmalıdır. Bu gibi durumlarda iş doyumu çalışanların etkinliğinin değerlendirilmesi açısından iyi bir gösterge olabilir. Yüksek seviyede iş doyumuna sahip olma işgörenin duygusal ve fiziksel olarak iyi olduğunu gösterir. İkincisi, işgörenin davranışları sahip olduğu iş doyumuna bağlı olarak, işletmenin etkinliğine ve aktivitelerine etki etmektedir. Bu ifadeden anlaşılacağı üzere, iş doyumu işgörenlerin olumlu davranışlar sergilemesini sağlarken tam tersi durumda işgörenlerin sahip olduğu iş doyumsuzluğu olumsuz davranışlar sergilemelerine neden olabilmektedir. Üçüncü ve son olarak, iş doyumu örgütsel faaliyetlerin göstergesi olarak hizmet edebilir. İş doyumunun değerlendirilmesi yoluyla, farklı organizasyon birimlerindeki farklı memnuniyet seviyeleri tanımlanabilir, ancak performansın artırılması için hangi örgütsel birim değişikliklerinin yapılması gerektiği konusunda iyi bir gösterge olabilir. Fred Luthans'a göre ise iş doyumunun üç önemli yönü vardır (Sevimli ve İşcan, 2005: 56): hissedilebilir.

- İş doyumu, duygusal yönü ağır basan bir kavramdır. Çünkü görülemez ve sadece

- İş doyumu, genellikle çıktıların beklentileri ne derece karşıladığı ile ifade edilebilir.

- İş doyumu, birbiriyle ilgili birçok tutumu da beraberinde getirir. Bunlar genellikle iş, ücret, terfi olanakları yönetim tarzı, çalışma arkadaşları vb. tutumlardır.

\section{Turist Rehberliği ve İş Doyumunun Önemi}

Turizm sektörü emek yoğun bir sektördür. Bu sektördeki turizm işletmelerinde kaliteli hizmet üretip sunmak için iş doyumu stratejik bir öneme sahiptir. Kaliteli hizmet sunmanın temel yolu ise, becerikli ve işine kendini yoğunlaştırmış, performansı ve iş doyumu yüksek işgörenlerin varlığından geçmektedir. İş doyumu, turizm sektörünün önemli unsurlarından biri olan Turist rehberleri açısından büyük bir öneme sahiptir. Çünkü zaman kavramı olmadan yoğun iş temposunda çalışan turist rehberleri, farklı müşterilere hizmet vermektedir. Bu nedenle Turist rehberlerinin, işinden doyum elde edememesinden ve bunun sonucunda verimli çalışamayacağından dolayı müşteri memnuniyeti sağlaması mümkün 
Turist Rehberliği Dergisi (TURED) \& Yı1. 2018, Cilt. 1, Sayı. 1

Journal of Tour Guiding (JOTOG) \& Year. 2018, Volume. 1, Issue. 1

olmayabilir Turist rehberlerinin hizmet kalitesinin yükselmesinde iş doyumunun sağlanması oldukça önemli yer tutmaktadır (Köroğlu, 2012: 278).

Turist rehberi, turizm sektöründe arabulucu olarak, ziyaret edilecek yer, seyahat acentesi ve turist arasında köprü görevi gören kişidir. Turizm sektörünün vazgeçilmez unsurlarından biri olan turist rehberi, turizm sektöründe önemli görevler ve sorumluluklar üstlenir.

Turist rehberinin tutum ve davranışları, seyahat acentesinin hizmet kalitesini doğrudan etkiler. Turist rehberi, işin etkili oluşu ve kalitesini, müşterilerin memnuniyetini ve seyahat acentesinin imajını ve ününü etkiler. Turist rehberinin iş doyumu sağlaması, turizm sektöründe hem müşterilerin memnuniyeti hem de seyahat acenteleri üzerinde çok önemli bir etkiye sahiptir (Wang, 2017: 1319). Turist rehberleri zaman zaman farklı nedenlerden dolay1 iş doyumsuzluğu yaşamaktadırlar. Bunlar incelendiğinde doyumsuzluğa sebep olan birçok faktör bulunmaktadır. Özellikle turist rehberlerinin mesleklerinde karşılaştığı zorluklar turist rehberlerinin iş doyumsuzluklarının başlıca sebeplerindendir. Mesleki sorun ve engeller açısından bakıldığında, acentelerin Bakanlığın belirlemiş olduğu taban ücretleri ödememesi veya ödemelerin geciktirilmesi, bahşiş oranlarının düşüklüğü, taban yevmiye altında çalışan rehberlerin varlığı, rehberlerin acenteler tarafindan satış yapmaya zorlanması, çalışma saatlerinin uzunluğu ve düzensizliği, aşırı seyahat etme, özel yaşamın olumsuz etkilenmesi, düzensiz yaşam, sosyal hayatın kısıtlanması, özel günlerde dahi çalışma zorunluluğu, bayanların aile sorumlulukları nedeniyle erkeklere kıyasla daha az tura çıkabildikleri, fiziksel olarak yıpratıc1 ve yorucu bir meslek olması, sergilenen fiziksel performansindan dolayı sağlık sorunlarının ortaya çıkması, duygusal emeğin yoğun olması, mesleğin mevsimsellik özelliği göstermesi ve dolayısıyla iş güvencesinde sorun yaşanması, turların sürekliliğinin olmaması, rehberliğin meslek olarak görülmemesi, cinsiyet ayrımının yapılması gibi negatif mesleki algılamaların ortaya çıktığı görülmektedir (Güzel, Türker ve Şahin, 2014: 177). Bu faktörlerden dolayı turist rehberleri iş doyumsuzluğu yaşayabilmektedir.

Diğer nedenler açısından bakıldığında çağın hastalığı olan stresten dolayı turist rehberleri yine iş doyumsuzluğu yaşayabilmektedirler. Stres, kelime anlamı olarak "kuvvetli çaba" anlamına gelmektedir. İngilizce kökenli bir kelime olan stres kavramı, bir çeşit zorlayıcı güç kullanma ve buna bağlı olarak fizyolojik ve psikolojik etki anlamına gelmektedir (Güzel, Altıntaş ve Şahin, 2017: 198). Strese neden olan stres kaynakları bulunmaktadır. Bunlar: çevresel, kişisel ve örgütsel (iş ortamıyla ilgili) faktörlerdir (Köroğlu, 2011: 235-239). Çevresel faktörler, ölüm, duygu patlamaları, ayrılık ve başaramama gibi durumlarda ortaya çıkan faktörlerdir. Bireysel faktörler, ailesel problemler, maddi sıkıntılar, alkol, sigara, uyuşturucu kullanımı gibi faktörlerdir. İş ile ilgili (örgütsel) faktörler ise, yaptıkları mesleğe ilişkin yükümlülük ve sorumluluklar, işin içeriği ve kapsamı bu faktörler arasında değerlendirilebilir (Güzel, Altıntaş ve Şahin, 2017: 199-200).

Yukarıda ifade edilen sebeplerden dolayı turist rehberleri iş doyumsuzluğu, yaşam tatminsizliği yaşayabilmekte, olumsuz mesleki tutuma sahip olabilmekte, motivasyon eksikliği ve işten ayrılma gibi durumlarla karşı karşıya kalabilmektedirler. Turist rehberlerinin yüksek iş doyumuna sahip olabilmeleri için rehberlerin mesleklerini icra ederken karşılaştığı sıkıntı ve sorunların en aza indirilmesi gerekmektedir. Bu nedenle turist rehberlerinin yukarıda ifade edilen sorunlarının ortadan kaldırılması ya da en düşük seviyeye indirilmesi önem taşımaktadır. Çünkü iş doyumu mikro ve makro açıdan incelendiğinde hem işverenlere hem de işgörenlere sağladığ 1 faydalar bulunmaktadır. İş doyumunun sağladığ faydalar tablo1'de gösterilmiştir. 
Turist Rehberliği Dergisi (TURED) \& Yıl. 2018, Cilt. 1, Sayı 1

Journal of Tour Guiding (JOTOG) \& Year. 2018, Volume. 1, Issue. 1

İş doyumunun faydaları mikro açıdan incelendiğinde işletmeler sahip oldukları imkânları etkin bir şekilde kullandığında diğer rakipleriyle rekabet etme gücü artar. İşletmelerin sektörde uzun süre kalıcı olabilmesi sadece sahip olunan kaynakların verimli kullanılmasıyla sağlanmaz. Kaynakları verimli bir şekilde kullanacak, acentenin koymuş olduğu kurallara bağlı, inisiyatif kullanabilen, işletmeye sadık, işletme çıkarlarını kendi çıkarlarının üstünde görebilen işgörenlere ihtiyaç vardır. İşine bağlı çalışanlar, verimliliği arttırabilir, beraber çalıştı̆̆ iş arkadaşlarıyla uyumlu çalışabilir, işletmede güven ve huzur ortamı oluşturabilirler, kalite artar, karlılık artar, maliyet azalır. Bu durum turist rehberleri içinde aynıdır. Acente elinde olan imkânları ve kaynakları verimli kullanabilmesi için turist rehberleriyle birlikte hareket etmesi gereklidir. Tur programı hazırlanırken güzergâh bilgisi, mola yerleri, gezilecek yerler vb. gibi konularda sahada aktif olarak çalışan rehberlerle iletişim halinde olunması ve rehberlerin bilgi ve tecrübesinden faydalanılması gereklidir. Acente, ayn zamanda turist rehberlerine en az taban yevmiye verme, turist rehberlerine yetki devri yapma, turistlerin karşılaştı̆̆ sorunların çözümünde ve turist rehberlerinin herhangi bir konuda kolayca karar almalarında teşvik edici olabilmelidir. Acente tarafından güçlendirilmiş turist rehberi, acentenin haklarını içtenlikle savunabilir, turistlere bilgi aktarırken veya herhangi bir sorun yaşadıklarında elinden geleni yapmaya çalışır. Birlikte çalıştığ 1 arkadaşlarıyla uyumlu çalışabilir ve acentede huzur ortamı oluşur. Böylece turist rehberleri çalıştıkları acenteyi kendi işleri gibi algılar, motivasyon ve performanslarını en üst seviyeye çıkarırlar. Bu durum acentenin karlılığını arttırır, maliyetlerini azaltır, acentede oluşabilecek iş devir hızını düşürür, müşterilerin katıldıkları turlardan zevk almaları acente için müşteri sadakati oluşturur.

\section{Tablol. İS Doyumunun Mikro ve Makro Açıdan Sağladĭ̆ Faydalar}

\begin{tabular}{|c|c|}
\hline Mikro Acııan Faydaları & Makro Acııdan Faydaları \\
\hline $\begin{array}{l}\text { İşletme kaynaklarının etkin kullanılması, } \\
\text { Verimliliği artırması, } \\
\text { Huzurlu bir çalışma ortamının oluşması, } \\
\text { İşgören ve işveren arasında güvene dayalı } \\
\text { bir anlayışı̂kkim kılması, } \\
\text { Faaliyetlerde kalitenin artması, } \\
\text { Maliyetleri azaltması ve kârlılığı } \\
\text { artırması, } \\
\text { İșletmeye rekabet avantajı katması. }\end{array}$ & $\begin{array}{l}>\text { İş tatmini dolayısıyla yaşam tatmini yüksek } \\
\text { bireylerden oluşan bir toplum meydana } \\
\text { gelmesi, } \\
>\text { İstihdam politikalarının öneminin artması, } \\
\text { Toplumda yaşam doyumu yüksek olan } \\
\text { insanlar dolayısıyla güven ortamının } \\
\text { sağlanması, } \\
>\text { İşletmelerin kârlılığının artması ile devletin } \\
\text { vergi gelirlerinin artması }\end{array}$ \\
\hline
\end{tabular}

Kaynak: Berry, L.M., (1997)'den akt. Kırcı Çevik ve Korkmaz, 2014: 128

Rehberlerin iş güvencelerinin sağlanması, çalışma koşullarının iyileştirilmesi ve ücretlerinin arttırılması özellikle ücret doyumsuzluğunun önlenmesi devamsızlık ihtimalini ve işten ayrılma niyetini de azaltması bakımından önem taşımaktadır. Böylece ücret ve iş güvencesi doyumsuzluğunun önlenmesi, rehberlerin aynı acentelerle uzun süreli çalışma ihtimalini de arttıracaktır (Köroğlu, 2012: 287).

Ayrıca kaçak rehberlik mikro açıdan irdelendiğinde nitelikli rehberlerin meslekten ayrılmalarına ve işsizliğe neden olmaktadır. Kaçak çalışan yerli ve yabancı tur liderleri ile tur temsilcileri rehberlik mesleğinin imgesini olumsuzlaştırmaktadır. Kaçak rehberlik sonucunda ücretler düşmekte ve rehberlik mesleği toplum tarafından yanlış algılanmaktadır. $\mathrm{Bu}$ durum verimsizliğe ve işgören devir hızının ve maliyetlerin artmasına neden olmaktadır. (Yarcan, 2007: 40).

Turist rehberi açısından bakıldığında ise ciddi bir gelir elde ettiğinden ve mesleklerini icra ederken turistler tarafından takdir edilme, saygınlık görme ve mesleğin tek başına çalışma imkânı vermesi, işe bağlılığı, motivasyonu, performansı, morali, mesleki 
tutumu olumlu etkilerken işten ayrılma niyeti ve acente yetkilileri ve iş arkadaşlarıyla çatışma yaşama gibi durumların ortadan kalkmasına ve turist rehberlerinin iş doyumu sağlamalarına vesile olabilirler. Mesleklerinde doyum sağlayan bireyler aynı zamanda toplumun fertleri olduğundan yaşam doyumu yüksek bireylerden oluşan toplum meydana getirirler. Refah ve eğitim seviyesi yüksek bireylerin olması güven ortamı yaratabilir. Güven ortamının olması istihdamı arttırırken devletin vergi gelirlerini yükseltir, işsizliği azaltır. Güvenli turistik bölgeler çekim merkezi haline gelir ve ülkelerin milli gelirlerini arttırır, turistik merkezlerdeki konaklama, yeme-içme, ulaştırma, rehberlik hizmetleri gibi hizmetlerin talep görmesini sağlayabilir. Dolayısıyla turizm sektörünün önemli temsilcilerinden olan turist rehberlerinin de gelir ve refah seviyesi, yaşam doyumu, işe bağl1lı̆̆ , mesleki tutumu ve iş doyumu olumlu bir şekilde etkilenir.

İş doyumunun rehberler açısından önemi incelendiğinde iş doyumunun verimlilik, işe bağlılık, yaşam doyumu ve moral açısından sağladığı faydalara izleyen kısımda kısaca değinilmiştir.

İş Doyumu ve Verimlilik: İş doyumu ve verimlilik arasında yakın bir ilişsi bulunmaktadır. İşinden memnun olan kişilerin çalışma koşulları ve moralleri daha yüksek olmakta ve işlerine olan bağlılıkları çalışanların daha çok verim almalarını ve motivasyonlarının yüksek olmasını sağlamaktadır (Çiftçi, 2014: 30). İşinden ödüllendirme, prim ya da izin gibi ekstra getirileri sağlayan kişilerin iş doyumundan beklentileri artacağ gibi, çalışanların da işlerinden duydukları başarma hissi ve işlerini kabullenmeleri, hem yöneticilere ve şirketin kar oranlarını artırmasına yardım etmekte hem de çalışanların iş verimliliğinde iş doyumuna ulaşmalarını kolaylaştırmaktadır (Deveci, 2014: 45).

İş Doyumu ve İşe Bağlılık: İşe bağl1lık, işgörenin işini benimseme derecesidir. İş tatmini ile işe ve örgüte bağlılık arasında anlamlı ve aynı yönde bir ilişki vardır. Yüksek iş tatminine sahip olan turist rehberlerinin çalıştığı işletmeyi sahiplendiği, işe bağlılı̆̆ının arttığ 1 ve isteğe bağlı işgören işgücü devir hızı oranının azaldığ1 saptanmıştır. İşe bağl1lığ1 yüksek olan bir turist rehberlerini güdülemek, yönetmek ve örgütün amaçları doğrultusuna yöneltmek daha kolaydır. Buna karş1lık, iş tatminsizliği sonucu işe bağl1lı̆̆ düşük fakat çeşitli nedenlerden dolayı çalışmak zorunda olan turist rehberleri, işletme içinde olumsuz davranışlar ortaya koymaya başlarlar. Bu tür rehberlerde her konuyla ilgili sık şikâyetler, işletme içinde ve dışında işletme hakkında olumsuz eleştiriler, diğer rehberlerin morallerini bozma çabaları, işi yavaşlatma, işe devamsızlık ve sonuçta da işten ayrılma gibi nihai davranışlar gözlemlenebilir (Akıncı, 2002: 8).

İş ve Yaşam Doyumu: Yaşam doyumu kavramı, bireyin çalışma yaşamı ve çalışma dış1 yaşamdaki doyumu ifade etmektedir. Turist rehberinin iş yaşamında geçirdiği zaman dilimi dikkate alındığında iş doyumu ile yaşam doyumu arasında ilişkinin var olması şaşırtıcı değildir. İşten sağlanan doyum ya da işten kazanılan tecrübelerin, turist rehberinin çalışma dışı yaşamını, diğer bir ifade ile yaşamın bütününü olumlu etkilediği sonucu çıkmaktadır. Turist rehberlerinin iş dışı başarılarının da, işteki başarıları üzerine etkisinin de büyük olduğu düşünülmektedir. Diğer yandan, çalışma yaşamındaki doyumsuzluk, mutsuzluk, hayal kırıklığ1 ve isteksizlik halleri, turist rehberlerinin genel yaşamına etki ederken; turist rehberlerinin yaşamdan da doyum almamaya başlamasına neden olabilmektedir. Bu durum turist rehberlerinin çevresini, ailesini ve arkadaşlık ilişkilerini de olumsuz etkileyerek, fiziksel ve ruhsal sağlı̆̆ını bozabilmektedir (Keser, 2005: 81).

İş Doyumu ve Moral: Moral kavramı yapılan değerlendirmelere göre, kişilerin işin gidişatı hakkında verdikleri olumlu ya da olumsuz tepkileri, işin işleyişine göre insanların motivasyon düzeylerinin artması ya da azalmasını ifade eden bir kavramdır. Morali yüksek 
olan kişilerin işlerine daha fazla hakim oldukları, moral bozukluğuna uğramış kişilerin ise kendilerini kötü ve bitkin hissettikleri, işlerine odaklanamadıklarını ortaya koymaktadır (Özdemir, 2016: 76).

İyi motive olmuş ve iş doyumuna ulaşmış turist rehberleri daha yüksek morale sahip oldukları için işyerine olan faydaları yüksek olur. Yüksel, çalışanların moral ve motivasyonun yüksek olması çalışanlar ve çalışma düzeninde olumlu etkilerin bazıları şunlardır (Kamiloğlu, 2014: 25):

$>$ Morali iyi olan bir turist rehberi işini daha neşeli ve enerjili yerine getirir.

$>$ Turist rehberleri, çalışmaya daha istekli olur. İşyerinin zor durumlarında, çaba gösterirler.

$>$ Turist rehberleri işyerinin hedefleri doğrultusunda iş birliği isterler.

$>$ Turist rehberleri yöneticilere ve işyerine karşı bağl1l1k duyarlar

$>$ Motivasyonun yüksek olması, Turist rehberlerinin çalışma arzusunu yükseltir.

$>$ Turist rehberleri, yönetmeliklere, iş kurallarına ve emirlere isteyerek uyarlar ve olumlu bir disiplin kurulur.

$>$ Yüksek moral, işgücü devri ve devamsızlı üzerinde de olumlu etkiler yapar.

$>$ Yüksek moral personel devir hızı ve devamsızlı̆̆ı azaltır. Dolayısıyla maliyet de azalır.

Yukarıda ifade edilen nedenler göz önünde bulundurularak turist rehberlerinin iş doyumlarını üst seviyelere taşıyacak çalışmaların bir an önce ilgili tüm paydaşlarca yapılması turist rehberleriyle ilişki içinde olan tüm sektör temsilcileri ve çalışanları açısından da fayda sağlayacaktır. Çünkü doyum, enerjik olmayı, performans ve motivasyon artışını, bağl1lığ 1 , yaşam doyumunu, işin gerektirdiği ciddiyet ve sorumluluğu arttırırken, iş devir hızını, isteksizliği, işe geç gelme, işe devamsızlık gibi olumsuz durumların ortaya çıkmasını da engellemektedir.

\section{Sonuç ve Öneriler}

İş doyumu, son zamanların en önemli araştırma konularından biridir. Çünkü teknolojik gelişmelerin hızlanması, iletişimin kolaylaşması işveren konumunda bulunanların işletmelerini daha ileriye taşımak, kendileri için işgörenlerin işletmenin çıkarlarını korumalarını sağlamak, işgören sadakati yaratmak, üretimin daha verimli hale gelmesini sağlamaları açısından işverenlerin yanlarında çalışan kişilere değer vermeleri gerekmekte hatta değer verdiklerini göstermeleri gerekmektedir. Böylelikle kendini değerli hisseden işgören işletmenin çıkarlarını her şeyden önce tutup rakipleri karşısında zor duruma düşmemesi için kendi işletmeleri için canla başla çalışacaklardır. Aynı durum turist rehberleri içinde geçerlidir. Turizm sektörü mesai kavramı olmayan bir sektördür. Turist rehberleri de turistlerle çok fazla zaman geçiren ve onlarla yüz yüze iletişim kuran işgörenlerdir. Acente tarafindan görevlendirilmiş temsilcilerdir ve aynı zamanda ülkelerin gönüllü büyükelçileridir. $\mathrm{Bu}$ nedenle turist rehberlerinin iş doyumlarının pozitif yönde olması önemlidir. Çünkü turistleri bilgilendiren, sağlık ve parasal konularla ilgilenen kişilerdir. Turistlerinde yabancı bir ülkede olmasından dolayı itibar edebileceği tek kişi kendilerine refakat eden turist rehberleridir. Turist rehberlerinin iş doyumlarını ortaya koymak ve arttırmak için çalışmalar yapılmıştır.

$\mathrm{Bu}$ çalışma doğrultusunda işveren konumundaki acenteler, temsilcileri olan turist rehberlerinin iş doyumlarını arttırarak maddi ve manevi anlamda kazanç elde edebilirler. Çünkü doyum sağlamış bir turist rehberi acentenin reklamını en iyi şekilde yaptığı gibi, 
Turist Rehberliği Dergisi (TURED) \& Yı1. 2018, Cilt. 1, Sayı. 1

Journal of Tour Guiding (JOTOG) \& Year. 2018, Volume. 1, Issue. 1

haklarını korur, acentenin müşterilerine daha yardımsever ve ilgili davranır. Kazançlar artarken giderlerin maliyetlerini de azaltabilir. İfade edilen seviyeye acentelerin ulaşabilmesi için acenteler turist rehberlerine, en az taban yevmiye vermeli, rehberlerin boş zamanlarında aileleriyle birlikte tatil yapmalarını teşvik etmeli, sürekli çalıştıkları rehberlerine sağlık ve iş güvencesi sunmalıdır. İş güvencesi, turist rehberleri için hayati bir önem taşır. Turist rehberlerine olağanüstü durumlar dışında, çalışkan ve başarılı olduğu sürece işini kaybetmeyeceği güvencesi verildiği takdirde, turist rehberleri daha huzurlu çalışacaktır. Çünkü iş huzuru, iş doyumunu arttıran önemli bir unsurdur.

Ayrıca acenteler çalıştıkları rehberlere sigorta yapmalı, yapılan satışlardan eşit pay vermeli, turist rehberlerinin fikirlerini ve tavsiyelerini önemsemeli, rehberlerin vereceği kararları desteklemeli ve arkasında durmalı, yetki devri yapmalı, yoğun dönemlerde (bayram, yılbaşı vb. günlerde) prim vermeli, belirli aralıklarla rotasyon yapmalı (farklı bölgelere tura göndermeli), çalışanlarının doğum günü, evlilik yıl dönümleri vb. günlerini hatırlamalı ve küçük kutlamalar yaparak rehberlere değer verdiğini hissettirmelidir. Böylece turist rehberleri kendisini çalıştığı acentede sadece sıradan bir işgören olarak algılamaz, aileden biri gibi görüp bu bilinçle mesleğini icra eder.

Gelecekte iş doyumuyla ilgili çalışmalar yapmak isteyen araştırmacılar iş doyumu değişkenin alt boyutları olan içsel ve dışsal doyum düzeyleri üzerinde araştırmalar yapabilir. Turist rehberlerinin içsel ve dişsal doyumları belirlenerek bir karşılaştırma yapılabilir. Ayrıca içsel ve dışsal doyumları etkileyen etmenlerin neler olduğu ve içsel ve dışsal doyum düzeylerinin nasıl arttırılması gerektiği konusunda öneriler getirilebilir. İş doyumu değişkeni farklı değişkenlerle bir araya getirilerek turist rehberlerinin farklı yönlerinin iş doyum düzeylerine hangi yönde ve ne kadar etki ettiği ortaya konulabilir. Farklı türde araştırma teknikleri kullanılarak nitel veya nicel desenli ya da hem nitel hem de nicel yöntemler kullanılarak çalışmalar gerçekleştirilebilir. Geçmişten günümüze gelen rehberlerin iş doyumlarının düşük seviyede kalmasına neden olan mesleki sorunlar tekrar gözden geçirilerek ilgili kurum ve kuruluşlarla bu sorunlar paylaşılabilir, kronikleşmiş sorunlara çözümler getirilebilir.

Turist rehberlerinin meslekleriyle ilgili özellikle son dönemlerde karşılaştıkları kaçak rehberlik faaliyetleri, taban altı yevmiye teklif edilmesi, meslektaşların etik kurallara uygun davranmaması, rehberliğin meslek olarak kabul edilmeyip kolay bir iş olarak görülmesi, devlet nezdinde zor zamanlarda herhangi bir desteğin olmaması, emeklilik ve sağlık güvencesinin olmayışı gibi temel nedenler turist rehberlerinde hem olumsuz mesleki tutumu hem de iş doyumsuzluğunu hep canlı tutmuştur. Bu nedenle turist rehberlerinin iş doyumlarını arttırmak için rehberlerin ülkedeki temsilcisi konumundaki TUREB, devlet nezdinde girişimlerde bulunmalı ve rehberlerin koşullarının iyileştirilmesi, devlet desteği, teşvik vb. gibi haklardan faydalanması için çalışmalar yapmalıdır. Ayrıca kaçak rehberlik faaliyetlerinin sonlandırılması 6326 sayılı kanunla belirlenmiş hakların korunması için bölgesel meslek odaları, Valilik, İl Kültür Turizm Müdürlükleri, TÜRSAB bölgesel yönetimleri ve kolluk kuvvetleriyle sürekli denetimler yapılmalıdır. Yapılan bu denetimler meslek odalarının web siteleri aracılığıyla ve whatsapp vb. gibi iletişim platformlarından rehberlerle paylaşılmalı ve mesleğin statüsünün korunduğu tüm rehberlere ilan edilmelidir. Ayrıca çalışma kartının alınması konusu tüm paydaşlarla tartışılmalı ve çalışma kartı sadece turizm rehberliği bölümünden lisans düzeyinde mezun olanlara verilmelidir. Sadece nadir dillerde (İzlandaca, Gürcüce vb. gibi) Bakanlık tarafından kurslar açılmalı ve çalışma kartı dağıtılmalıdır. İngilizce, Almanca, Fransızca gibi diller için kesinlikle Bakanlık tarafından kurslar açılmamalıdır. Nitekim konuyla ilgili olarak gerçekleştirilen çalışmalar (Köroğlu,

Kabakulak; Turist Rehberleri Açısından İş Doyumunun Önemi / The Importance of Job Satisfaction in Terms of 
2011; Özdemir, 2016; Gökdemir, 2017; Kabakulak, 2018) yukarıdaki açıklamaları destekler niteliktedir.

Yapılan çalışmalar incelendiğinde turist rehberlerinin genel iş doyumlarının orta düzeyde olduğu görülmektedir (Köroğlu, 2011; Özdemir, 2016; Gökdemir, 2017; Kabakulak, 2018). Turist rehberlerinin genel iş doyumlarının 2011 ile 2018 yılları arasında orta düzeyde çıkmış olması turist rehberliği mesleğinin bazı sorunları atlatamamış olmasıyla açıklanabilir. Köroğlu (2011) tarafindan yapılmış olan doktora çalışması döneminde henüz turist rehberliği bir meslek değildi, yasası bulunmamaktaydı. Turist rehberlerinin çok az kısmı meslek odalarına kayıtlıydı. Meslek odalarına üye olma zorunluluğu yoktu. Çalışma kartının alınması ile ilgili eğitim açısından birlik bulunmamaktaydı. Nadir dillerdeki rehber sayısı azdı. Aynı zamanda Batman (2003); Karamustafa ve Çeşmeci (2006); Yarcan (2007); Güzel, Türker ve Şahin (2014); Taştan ve Genç (2017) turist rehberlerinin meslekleriyle ilgili karşılaştıkları sorunları incelemiştir. Sorun olarak; emekliliğin olmayışı ya da geç oluşu, fiziki güce dayalı olması, devlet desteğinin olmaması vb. şeklinde çoğaltılabilir. Ancak bu sorunlar o dönemde de daha sonraki dönemlerde tekrarlanan çalışmalarda ortaya çıkmıştır. Yani var olan problemlere çözümler üretil(e)memiş problemler kronikleşmiştir. $\mathrm{Bu}$ durum 2000'lerden başlayarak 2018 yılına kadar turist rehberlerinde iş doyum düzeylerinin orta seviyenin üstüne çıkamamasına neden olmuştur. Dolayısıyla yazılmış olan tezler ve makaleler turizm sektörünün en önemli temsilcilerinden biri olan turist rehberlerinin yıllardır iş doyumlarının artmasına çare olamamıştır.

\section{Kaynakça}

Akıncı, Z. (2002). Turizm Sektöründe İşgören İş Tatminini Etkileyen Faktörler: Beş Yıldızlı Konaklama İşletmelerinde Bir Uygulama. Akdeniz İI. I.B.F. Dergisi, (4), 1-25.

Aydoğdu, Ü. R., Karamustafaoğlu, O. ve Bülbül, M. Ş. (2017). Akademik Araştırmalarda Araştırma Yöntemleri ile Örneklem İlişkisi: Doğrulayıcı Doküman Analizi Örneği. Dicle Üniversitesi Ziya Gökalp Eğitim Fakültesi Dergisi, 30, 556-565.

Aziri, B. (2011). Job Satisfaction: A Literature Review. Management Research And Practice, 3 (4), 77-86.

Berry, L.M., (1997). Psychology at Work, McGraw Hill Companies Inc., San Francisco akt. Kırcı Çevik, N. ve Korkmaz, O. (2014). Türkiye'de Yaşam Doyumu ve İs Doyumu Arasındaki İliş̧inin İki Değişkenli Sıralı Probit Model Analizi. Niğge Üniversitesi I.I. B.F. Dergisi, 7 (1), 126-145.

Boyle, A., and Arnott, A. (2004). What Tour Guide Stories can Tell us about Learning, Education and Training: A Case Study in The Top End Of The Northern Territory. Council for Australian Tourism and Hospitality Education (cauthe) Conference (86-94), University Of Queensland. Brisbane, Qld, Australia. 10-13 February.

Brito, M. 2012. "Cultural Tourists Requests from Their Tourist Guides". International Journal of Management Cases. 14 (1), 266-282

Çiftçi, M. (2014). Eğitim Araştırma Hastanesi Ameliyathane ve Yatakl Servis Biriminde Görev Yapan Hemşirelerinin İş Doyumunun Karşılaş̧tırılması. Yayınlanmamış Yüksek Lisans Tezi, Haliç Üniversitesi: İstanbul.

Deveci, S. (2014). Sağlık Çalışanlarında İş Doyumu ve Yaşam Doyumu İlişkisi (Antalya Atatürk Devlet Hastanesi Hemşireler Örneği). Yayınlanmamış Yüksek Lisans Tezi: İstanbul.

Eren, E. (2004). Örgütsel Davranış ve Yönetim Psikolojisi (8. Baskl). İstanbul: Beta Yayınevi.

Geva, A. and Goldman A. (1991). Satisfaction Measurement in Guided Tours. Annals of Tourism Research. 18 (2), 177-185. 
Ghiselli, R. F., Lalopa, J. M., Bai, B. (2001). Job Satisfaction, Life Satisfaction and Turnover Intent: Among Food Service Managers. Cornell Hotel and Restaurant Administration Quarterly, 42 (2), 28-37.

Gökdemir, S. (2017). Turist Rehberlerinde İş Doyumu ve Tükenmişlik İişkisi: Bir Alan Araştırması. Yayınlanmamış Yüksek Lisans Tezi, Balıkesir Üniversitesi, Balıkesir.

Güzel, Ö., Altıntaş, V. ve Şahin, İ. (2017). Turist Rehberliği Araştırmalarl Öngörüler ve Uygulamalar. Ankara: Detay Yayıncilık.

Güzel, Ö., Türker, A. ve Şahin, İ. (2014). Profesyonel Turist Rehberlerinin Algıladıkları Mesleki Engelleri Belirlemeye Yönelik Bir Araştırma. Gazi Üniversitesi Turizm Fakültesi Dergisi, 2, 173-190.

İrigüler, F , Güler, M . (2016). Emotional Labor of Tourist Guides: How Does it Affect Their Job Satisfaction and Burnout Levels?. Journal of Yaşar University, 11 (42), 113-123.

Kabakulak, A. (2018). Kişilik Özelliklerinin Mesleki Tutum ve İş Doyumuna Etkisi: Turist Rehberleri Üzerine Bir Araştırma. Yayınlanmamış Yüksek Lisans Tezi, Afyon Kocatepe Üniversitesi, Afyonkarahisar.

Kamiloğlu, B. (2014). Sağlık Çalışanlarında İş Doyumu ve Örgütsel Bağlllık (Merkezefendi Devlet Hastanesi Hemşireleri Örneği). Yayınlanmamış Yüksek Lisans Tezi, Beykent Üniversitesi: İstanbul.

Karamustafa, K. ve Çeşmeci, N. (2006). Paket Tur Operasyonunda Turist Rehberlerinin Karşılaştıkları Yönetsel Sorunlar Üzerine Bir Araştırma. Anatolia: Turizm Araştırmaları Dergisi, 1 (17), 70-86.

Keser, A. (2005). İş Doyumu ve Yaşam Doyumu İlişkisi: Otomotiv Sektöründe Bir Uygulama. Çalışma ve Toplum Dergisi, 4 (7), 77-96.

Kırcı Çevik, N. ve Korkmaz, O. (2014). Türkiye'de Yaşam Doyumu ve İş Doyumu Arasındaki İlişkinin İki Değişkenli Sıralı Probit Model Analizi. Niğde Üniversitesi İktisadi İdari Bilimler Fakültesi Dergisi, 7 (1), 126-145.

Köroğlu, Ö. (2011). İş Doyumu ve Motivasyon Düzeylerini Etkileyen Faktörlerin Performansla Illişkisi: Turist Rehberleri Üzerine Bir Araştırma, Yayınlanmamış Doktora Tezi, Balıkesir Üniversitesi, Balıkesir.

Köroğlu, Ö. (2012). İçsel ve Dışsal İş Doyum Düzeyleri İle Genel İş Doyum Düzeyi Arasındaki İlişkinin Belirlenmesi: Turist Rehberleri Üzerinde Bir Araştırma. Doğuş Üniversitesi Dergisi, 13 (2), 275-289.

Latif, M. S., Ahmad, M., Qasim, M. Mushtaq, M., Ferdoos, A. and Naeem, H. (2013). Impact of Employee's Satisfaction on Organizational Performance. European Journal of Business and Management, 5(5), 166-171.

Luthans, F. (2010). Organizational Behavior : An Evidence-Based Approach, (12th Ed.), New York, McGraw-Hill Companies, Inc.

Mak, A. H. N., Wong, K. K. F., Chang, R. C. Y. (2011). Critical Issues Affecting the Service Quality and Professionalism of The Tour Guides in Hong Kong and Macau. Tourism Management. 32: 1442-1452.

Özaydın M. M. ve Özdemir, Ö. (2014). Çalışanların Bireysel Özelliklerinin İş Tatmini Üzerindeki Etkileri: Bir Kamu Bankası Örneği, Issletme Araştırmaları Dergisi, 6 (1), 251281.

Özdemir, F. (2006). Örgütsel İklimin İş Tatmin Düzeyine Etkisi: Tekstil Sektöründe Bir Araştırma. Yayınlanmamış Doktora Tezi. Çukurova Üniversitesi: Adana.

Özdemir, Ö. (2016). Turist Rehberlerinde Personel Güçlendirme Uygulamalarının İş Doyumuna Etkisi. Yayınlanmamış Yüksek Lisans Tezi, Balıkesir Üniversitesi: Balıkesir. 
Rabotic, B. (2010). Professional Tourist Guiding: The Importance of Interpretation for Tourist Experiences. 20th Biennial International Congress: New Trends in Tourism and Hotel Management. University of Rijeka. Opatija, Croatia.

Raziq, A., and Maulabakhsh, R. (2015). Impact of Working Environment on Job Satisfaction. 2nd Global Conference on Business, Economics, Management and Tourism, 30-31 October, Prague, Czech Republic.

Sevimli, F. ve İşcan Ö. F. (2005). Bireysel ve İş Ortamına Ait Etkenler Açısından İş Doyumu. Ege Üniversitesi, İktisadi İdari Bilimler Fakültesi Akademik Bakış Dergisi, 5 (1-2), 55-64.

Sinha, D. and Shukla, S. K. (2013). Study of Job Satisfaction of the Employees of Private Sector Banks. International Journal of Education and Psychological Research (IJEPR), 2 (2), 33-40.

Spector, P.E. (1997). Job satisfaction: Application, Assessment, Causes and Consequences, Thousand Oaks, CA,Sage Publications, Inc.

Taştan, H. ve Genç, E. (2017). Turist Rehberlerinin Yaşadıkları Mesleki Zorlukların Cinsiyete ve Yillara Göre İncelenmesi. The First International Congress on Future of Tourism, Mersin University, pp.857-867, Mersin, Turkey, 2017.

TDK,(2018),http://www.tdk.gov.tr/index.php?option=com_gts\&arama=gts\&guid=TDK.GT S.5b30cfb4b2e877.14439326 (Erișim Tarihi: 25.06.2018)

TUREB, "Yasa", http://www.tureb.org.tr/tr/Page/Detail/60 (Erişim Tarihi: 25.06.2018)

Vieira, J. A. C. (2005). Skill Mismatches and Job Satisfaction. Economic Letters, 89, 39-47.

Wang, C. (2017). A Study on The Job Satisfaction of Tour Guides and its Influencing Factors. Advances in Computer Science Research (ACSR), 61, 1319-1323, 7th International Conference on Education, Management, Computer and Society (EMCS 2017).

WTFGA, "What is Tourist Guide", http://www.wftga.org/tourist-guiding/what-tourist-guide (Erişim Tarihi: 25.06.2018)

Yarcan, Ş. (2007). Profesyonel Turist Rehberliğinde Mesleki Etik Üzerine Kavramsal Bir Değerlendirme. Anatolia: Turizm Araştırmaları Dergisi, 18(1). 